Research Report No. 31/2007

\title{
Reviving the Modern Rule in the Interpretation of Tax Statutes: Baby Steps Taken in Canada Trustco, Mathew, Placer Dome and Imperial Oil
}

Jinyan Li

Osgoode Hall Law School of York University, JLi@osgoode.yorku.ca

David M. Piccolo

Follow this and additional works at: http:/ / digitalcommons.osgoode.yorku.ca/clpe

\section{Recommended Citation}

Li, Jinyan and Piccolo, David M., "Reviving the Modern Rule in the Interpretation of Tax Statutes: Baby Steps Taken in Canada Trustco, Mathew, Placer Dome and Imperial Oil" (2007). Comparative Research in Law \& Political Economy. Research Paper No. 31/ 2007.

http://digitalcommons.osgoode.yorku.ca/clpe/247 


\section{$J$ inyan Li and David Piccolo}

Reviving the Modern Rule in the Interpretation of Tax Statutes: Baby Steps Taken in Canada Trustco, Mathew, Placer Dome and Imperial Oil

EDTORS: Peer Zumbansen (Osgoode Hall Law School, Toronto, Director, Comparative Research in Law and Political Economy, York University), J ohn W. Cioffi (University of California at Riverside), Lindsay Krauss (Osgoode Hall Law School, Toronto, Production Editor) 

CLPE Research Paper 31/2007

Vol. 03 No. 06 (2007)

\title{
Jinyan Li and David Piccolo
}

\section{REVIVING THE MODERN RULE IN THE INTERPRETATION OF TAX STATUTES: BABY STEPS TAKEN IN CANADA TRUSTCO, Mathe W, Placer Dome AND Imperial OIL}

\begin{abstract}
Canada Trustco, Mathew, Placer Dome and Imperial Oil are landmark decisions of the Supreme Court of Canada in terms of their illumination on the principle of statutory interpretation. In these cases, the Court stated that the Income Tax Act should be interpreted in accordance with a "textual, contextual and purposive" approach. This amounts to a revival of the "modern rule" of statutory interpretation and a move away from the "plain meaning" approach previously adopted by the Court. This article argues that the steps taken by the Court in reviving the modern rule are merely baby steps, as many key questions remain inadequately addressed. The article first discusses the rise and fall of the modern rule in Canadian tax jurisprudence. It then analyzes each of the four decisions and highlights the contribution of each case to the development of the textual, contextual and purposive interpretation. The article concludes with some thoughts on the challenges facing the courts in establishing the "purpose" of provisions of the Act and offers some suggestions for moving forward.
\end{abstract}

Keywords: Canada Trustco, Mathew, Placer Dome, Imperial Oil, Income Tax Act, Canada, modern rule, statutory interpretation

JEL classification: K10, K34

Forthcoming in: Supreme Court Law Review

Author Contacts:

Jinyan Li

Osgoode Hall Law School, York University, Toronto ON

Email: jinyanli@osgoode.yorku.ca 
David Piccolo

Osgoode Hall Law School, York University, Toronto ON

Email: davidpiccolo@osgoode.yorku.ca 


\title{
REVIVING THE MODERN RULE IN THE INTERPRETATION OF TAX STATUTES: BABY STEPS Taken in Canada Trustco, Mathew, Placer DOME AND IMPERIAL OIL
}

\author{
Jinyan Li and David Piccolo*
}

\section{INTRODUCTION}

In 2005, the Supreme Court of Canada made two landmark tax decisions: Canada Trustco Mortgage Co. v. Canada ${ }^{1}$ and Mathew v. Canada. ${ }^{2}$ For the first time, the Court ruled on the application of the general antiavoidance rule (GAAR) and articulated a uniform approach to statutory interpretation on the basis of the "modern rule" - the "textual, contextual and purposive" (TCP) approach. The far-reaching implications of these decisions in GAAR jurisprudence have been well discussed elsewhere. ${ }^{3}$

* Jinyan Li is a Professor at Osgoode Hall Law School, email: jinyanli@osgoode.yorku.ca; David Piccolo is an LL.B. Candidate at Osgoode Hall Law School, email davidpiccolo@osgoode.yorku.ca

${ }^{1} 2005$ SCC 54 [Canada Trustco].

${ }^{2} 2005$ SCC 55 [Mathew]. This case and Canada Trustco, ibid., were heard together.

${ }^{3}$ See Benjamin Alarie, Sanjana Bhatia \& David G. Duff, "Symposium on Tax Avoidance After Canada Trustco and Mathew: Summary of Proceedings" (2005) 53 Can. Tax. J. 1010; Brian Arnold, "Confusion Worse Confounded - The Supreme Court's GAAR Decisions" (2006) 54 Can. Tax. J. 167 (hereinafter "Arnold, "Confusion Worse Confounded"); --, "The Long, Slow, Steady Demise of the General Anti-Avoidance Rule" (2004) 52 Can. Tax. J. 488; --, "Reflections on the Relationship between Statutory Interpretation and Tax Avoidance” (2001) 49 Can. Tax. J. 1; Patrick J. Boyle, William I. Innes \& Joel Nitikman, The Essential GAAR Manual: Policies, Principles and Procedures (Toronto: CCH Canadian, 2006); David G. Duff \& Harry Erlichman, eds., Tax Avoidance in Canada after Canada Trustco and Mathew, (Toronto: Irvin Law, 2007); Malcolm Gammie, "Barclays and Canada Trustco: Further Comment from a UK Perspective" (2005) 53 Can. Tax. J. 1047; Thomas E. McDonnell, "Restrictive View of Avoidance Transaction and Abusive Avoidance: Evans v. The Queen” (2006) Can. Tax. J. 461; Alan M. Schwartz, ed., GAAR interpreted: the general anti-avoidance rule (Toronto: Carswell, 2006). 
This article focuses on the importance of these decisions in statutory interpretation. Although it was unclear whether the TCP approach was limited to the GAAR, these two decisions represented a shift away from the literal or plain meaning approach towards a revival of the modern rule in the interpretation of the Income Tax Act (the "Act”). ${ }^{4}$

By coincidence, the Court had two more opportunities to revisit the issue of statutory interpretation in 2006. Placer Dome Canada Ltd. v. Ontario (Minister of Finance) ${ }^{5}$ made it clear that the TCP approach applies to tax statutes in general, including provincial tax statutes. In Imperial Oil Ltd. $v$. Canada, ${ }^{6}$ the Court further confirmed the application of the TCP approach, even when it was split on its application to the facts of the case.

This article critically assesses these four decisions in terms of their stance on statutory interpretation. Following this introduction, Part II provides a background for the shift and briefly overviews the rise and fall of the modern rule in Canadian tax jurisprudence. Part III discusses Canada Trustco and Mathew and the Court's thinking on the importance of the TCP approach and the guidelines on its application. Part IV reviews Placer Dome and examines the extent to which it advances the Court's thinking on purposive interpretation. Part V reviews Imperial Oil and highlights the major differences between the majority and the dissenting justices on the relevance and proof of legislative purpose or intent. Part VI argues that the revival of the modern rule in the form of the TCP approach is encouraging, even though the steps taken thus far merely represent "baby steps". There are strong signals that the Court will adhere to this approach. The article concludes with some thoughts on the challenges facing the courts in establishing the "purpose" of provisions of the Act and offers some suggestions for moving forward.

\footnotetext{
${ }^{4}$ R.S.C. 1985 (5 ${ }^{\text {th }}$ Supp.), c. 1.

${ }^{5} 2006$ SCC 20 [Placer Dome].

${ }^{6} 2006$ SCC 46 [Imperial Oil].
} 


\section{THE RISE AND FALL OF THE “MODERN RULE”}

\section{A. THE MODERN RULE}

The "modern rule" of statutory interpretation calls for "the words of an Act to be read in their entire context and in their grammatical and ordinary sense harmoniously with the scheme of the Act, the object of the Act, and the intention of parliament."7 This requires an examination of the meaning of the words used in the statute, the context of the provision within the statute, the scheme and object of the statute, and the legislative intent. It was adopted by the Supreme Court in Stubart Investments Ltd. v. Canada. ${ }^{8}$ This meant that tax statutes would be interpreted in the same manner as other statutes. ${ }^{9}$

The modern rule was further entrenched when section 12 of the Interpretation $A c t^{10}$ was enacted. It states that "every enactment is deemed remedial, and shall be given such fair, large and liberal construction and interpretation as best ensures the attainment of its objects."

${ }^{7}$ Elmer A. Dreidger, Construction of Statutes, $2^{\text {nd }}$ ed. (Toronto: Butterworths, 1983) at 87.

${ }^{8}$ [1984] 1 S.C.R. 536, [1984] C.T.C. 294, 84 D.T.C. 6305 [Stubart]. This case is known for its adoption of the modern rule of statutory interpretation as well as its rejection of the "business purpose" test as an anti-avoidance rule. In response to the second element, Parliament enacted a statutory anti-avoidance rule or GAAR in section 245 of the Act.

9 As discussed further, however, the Income Tax Act is still considered to be "different" from other statutes because of the inherent complexity and high level of technicality.

${ }^{10}$ R.S.C. 1985 , c. I-21. 


\section{B. THE RISE}

Traditionally, Canadian courts interpreted tax statutes strictly. This approach is perhaps best articulated in a dictum of the House of Lords in Partington v. A.G. (1869): ${ }^{11}$

... as I understand the principle of all fiscal legislation, it is this: if the person sought to be taxed comes within the letter of the law he must be taxed, however great the hardship may appear to the judicial mind to be. On the other hand, if the Crown, seeking to recover the tax, cannot bring the subject within the letter of the law, the subject is free, however apparently within the spirit of the law the case might otherwise appear to be.

Under the strict approach, if the language of the statute is not literally apt to catch the transaction at issue, then it is not subject to the statute. In other words, where there is doubt or ambiguity in the provisions that levy a tax, the ambiguity is interpreted in favour of the taxpayer. This interpretative approach was instrumental to the success of tax planning. The rationale for strict interpretation has often been related to "notions of personal liberty"12 and the confiscation of property. ${ }^{13}$

Canadian courts started to move away from the strict approach in the late 1970s. ${ }^{14}$ The rise of the modern rule gained momentum with Stubart. In

\footnotetext{
${ }^{11}$ L.R. 4 H.L. 100 (H.L.), 122, per Lord Cairns.
}

12 Randal N. Graham, Statutory Interpretation: Theory and Practice (Toronto: Emond Montgomery Publications, 2001) at 194.

${ }^{13}$ Robert Stevens, Law and Politics: The House of Lords as a Judicial Body, 1800-1976 (Chapel Hill: University of North Carolina Press, 1978) at 170-71.

${ }^{14}$ For a general discussion of statutory interpretation, see Brian Arnold, “The Supreme Court and the Interpretation of Tax Statutes - Again” (2006) 54 Can. Tax. J. 677; -"Confusion Worse Confounded"), supra note 3; -- "Statutory Interpretation: Some Thoughts on Plain Meaning”, Report of Proceedings of Fiftieth Tax Conference, 1998 Tax Conference (Toronto: Canadian Tax Foundation, 1999) 6:1-36; David G. Duff, “Justice Iacobucci and the 'Golden and Straight Metwand' of Canadian Tax Law” (2007) 57 U.T.L.J. 525; --, "Interpreting the Income Tax Act - Part 1: Interpretive Doctrines” (1999) 47 Can. Tax. J. 464; --, "Interpreting the Income Tax Act - Part 2: Toward a Pragmatic Approach” (1999) 47 Can. Tax. J. 741; David G. Duff et. al., Canadian 
Stubart, the Court gave two justifications for the development. First, the nature of the income tax laws had changed: "Income tax legislation, such as the federal Act in our country, is no longer a simple device to raise revenue to meet the cost of governing the community. Income taxation is also employed by government to attain selected economic policy objectives." " Second, the modern rule is helpful to "reduce the attraction of elaborate and intricate tax avoidance plans."16 Purposive interpretation was thus considered a tool to prevent tax avoidance. ${ }^{17}$

Subsequent to the Stubart decision, the Court broke further away from the traditional strict approach. For example, in Bronfman Trust v. The Queen $^{18}$, the Court disallowed the taxpayer's interest deduction because it was not used to earn income from business or property. The Court rejected the taxpayer's argument that the borrowed funds allowed the trust to indirectly earn income because to do so would open the availability of the deduction to a broader use than what was intended by Parliament. The Chief Justice stated: ${ }^{19}$

Parliament created subparagraph 20(1)(c)(i), and made it operate notwithstanding paragraph 18(1)(b), in order to encourage the accumulation of capital which would produce taxable income. Not all borrowing expenses are deductible.

income tax law, $2^{\text {nd }}$ ed. (Markham: Butterworths, 2006); Tim Edgar and Daniel Sandler, eds., Materials on Canadian Income Tax, $13^{\text {th }}$ ed. (Toronto: Irwin Law, 2005); Peter Hogg, Joanne Magee \& Jinyan Li, Principles of Canadian Income Tax Law, $5^{\text {th }}$ ed. (Toronto: Thomson/Carswell, 2005), c. 19; Vern Krishna, The Fundamentals of Canadian income tax, $8^{\text {th }}$ ed. (Toronto: Thomson/Carswell, 2004); Joel Nitikman and Derek Alty, "Some Thoughts on Statutory Interpretation in Canadian Tax Law - A Reply to Brian Arnold” (2000) 20 Tax Notes International 2185.

${ }^{15}$ Stubart, supra note 7 at 6322.

${ }^{16}$ Ibid., at 6322.

${ }^{17}$ Ibid., at 6322.

${ }^{18}$ [1987] 1 C.T.C. 117, 87 D.T.C. 5059 (S.C.C.).

${ }^{19}$ Ibid., at para. 28. 


\section{THE FALL}

In the early 1990s, the Court's stance on statutory interpretation changed. The modern rule continued to be cited, but its impact was reduced significantly by the rise of the "plain meaning" approach. One of the first cases to cause the fall of the modern rule is Antosko v. The Queen. ${ }^{20}$ The taxpayer purchased $\$ 5$ million in debt from a provincial agency for $\$ 10$ and the promise to run a failing company for two years. Interest income had accrued while the debt was in the provincial agency's hands, and when it became payable, the taxpayer deducted the amount that had accrued in the agency's hands under subsection 20(14) of the Act. The deduction was authorized by the literal language of the Act, which provided that, on the transfer of a debt obligation, any unpaid interest accrued to the date of the transfer is to be included in the transferor's income and deducted from the transferee's income. The transferor, being an agency of the provincial government, was exempt from tax so that it did not report or pay tax on the interest accrued up to the date of transfer. The Minister took the position that it was contrary to the object and spirit of the Act to allow the transferee taxpayer to deduct the accrued interest when the transferor was not taxable - essentially, the subsection designed to prevent double taxation was being used to create double non-taxation. The Court rejected the Minister's argument and allowed the deduction. Iacobucci J., writing for the Court, held that the taxpayer was entitled to rely upon the terms of the statute, which clearly entitled the transferee of a debt obligation to a deduction for the interest accrued to the date of transfer. Where the words of the statute were "clear and plain”, and where the legal and practical effect of the taxpayer's transaction brought the taxpayer within the words of the statute, then the statute had to be applied according to its terms regardless of the object and purpose of the provision. $^{21}$

The Court's decision in Friesen $v . R^{22}$ moved further away from the modern rule. The issue in this case was whether the taxpayer's land was

\footnotetext{
${ }^{20}$ [1994] 2 C.T.C. 25, 94 D.T.C. 6314 (S.C.C.).

${ }^{21}$ Ibid., at para. 25.

22 [1995] 2 C.T.C. 369, 95 D.T.C. 5551 (S.C.C.) [Friesen].
} 
inventory for the purpose of subsection 10(1) of the Act - if the land was inventory, the taxpayer would be able to deduct the unrealized loss on the property. The majority of the Court found that the land was inventory in subsection 248(1), and made it clear that the modern rule was falling out of favour:

In interpreting sections of the Income Tax Act, the correct approach, as set out by Estey J. in Stubary Investments Ltd. v. The Queen, [1984] 1 S.C.R. 536, is to apply the plain meaning rule. ${ }^{23}$

[T]he object and purpose of a provision need only be resorted to when the statutory language admits of some doubt or ambiguity. ${ }^{24}$

The above statements indicate that the Court, in Friesen misinterpreted the modern rule as adopted in Stubart to be the same as the plain meaning rule. That may explain why in subsequent cases ${ }^{25}$ the Court cited Stubart for establishing the modern rule as the proper approach of statutory interpretation, but paid lip service to it by giving a more literal interpretation of the statutory provisions and ignoring the "scheme of the Act, the object of the Act and the intention of Parliament." The Court dissected the modern rule into two parts. Find the plain meaning of the statutory text first. Only if that exercise fails in establishing an unambiguous interpretation may the court examine the "object or purpose" of the statutory provision. The Court rationalized its approach on the following ground:

It would introduce intolerable uncertainty into the Income Tax Act if clear language in a detailed provision of the Act were to be qualified by unexpressed exceptions derived from a court's view of the object and purpose of the provision ... ${ }^{26}$

${ }^{23}$ Ibid., at para. 10.

${ }^{24}$ Ibid., at para. 60 .

${ }^{25}$ See e.g. Ludco Enterprises Ltd. v. Canada, [2002] 1 C.T.C. 95, 2001 D.T.C. 5505 (S.C.C.).

${ }^{26}$ See e.g. Friesen, supra note 22 at para. 11. This quote originated from Peter Hogg's lecture notes, which were incorporated into Hogg and Magee, Principles of Canadian Income Tax Law, $1^{\text {st }}$ ed. (Toronto: Carswell, 1995) at 453-54. 


\section{CANADA TRUSTCO AND MATHEW: REVIVING THE MODERN RULE IN THE GAAR CONTEXT}

\section{A. GAAR REQUIRES A PURPOSIVE INTERPRETATION}

As mentioned already, Canada Trustco and Mathew were the first GAAR cases heard by the Supreme Court. Parliament enacted the GAAR (section 245 of the Act) to prevent abusive tax avoidance transactions without interfering with legitimate tax planning. Subsection 245(4) draws the line between legitimate and abusive tax avoidance by stating that GAAR does not apply to an avoidance transaction "where its may reasonably be considered that the transaction would not result directly or indirectly in a misuse of the provisions of this Act or an abuse having regard to the provisions of this Act, other than this section, read as a whole." What constitutes a "misuse" of the provisions of the Act or "abuse" of the provisions of the Act read as a whole? Obviously, the answer to these questions cannot be found by merely looking at the plain meaning of the provisions relied upon, or avoided by, the taxpayer in achieving tax avoidance. If the taxpayer cannot rely on the plain meaning of the specific statutory provisions (including some specific anti-avoidance provisions), the Minister would not have to use "the ultimate weapon" ${ }^{\text {"27 }}$ to deny the tax benefit resulting from the avoidance transactions. In order to give meaning to section 245, the court must look for something beyond the plain meaning of a statutory provision. As such, the court must look at the purpose of the provision and the intent of Parliament in enacting it. In other words, the modern rule is needed to interpret the GAAR. ${ }^{28}$

${ }^{27}$ Hill v. Canada (2002), [2003] 4 C.T.C. 2548, 2002 D.T.C. 1749 (T.C.C.) at para. 63.

${ }^{28}$ In this sense, the GAAR could be viewed as a statutory interpreting rule to codify the modern rule. 
Not surprisingly, the key issue in Canada Trustco and Mathew was the interpretation of subsection 245(4), that is, whether the transactions undertaken primarily for tax purposes were "abusive". ${ }^{29}$ According to the Court, the doctrine of "abuse" refers to the abuse of the "object, spirit and purpose" of the legislation. The process of determining "abuse" under subsection 245(4) involves two steps: first, interpret the provisions giving rise to the tax benefit to determine their object, spirit and purpose; second, determine whether the transaction falls within or frustrates that purpose. ${ }^{30}$

\section{B. CAnAda Trustco}

\section{THE CASE}

Canada Trustco had a significant amount of income from a portfolio of loans and leases. In order to minimize its tax liability, the taxpayer looked for tax structures that could shelter such income from tax. The structure under appeal in this case involved a series of transactions that were, in essence, a purchase and lease-back transaction. The goal was to generate "tax deductions" in excess of income so that the deduction could be used to shelter investment income.

Canada Trustco purchased trailers from a third party and concurrently subleased them back to the vendor. On the same day, further back-to-back transactions were undertaken to ensure that the financial risk for all parties was eliminated. As a result of these transactions, the positions of the parties involved were essentially unchanged with one major exception: technically, Canada Trustco had purchased the trailers (which are depreciable property and eligible for capital cost allowance deductions) and leased them back to the original "seller". Because the deductions exceeded the "lease income" during the first few years of the "lease", the deductions effectively reduced income from the existing portfolio of loans

${ }^{29}$ The Court collapsed the "misuse" and "abuse" elements into a single "abuse" test: Canada Trustco, supra note 1 at para. 43. For more comments on this aspect of the decisions, see Arnold (2006), supra note 3 at 187-89.

${ }^{30}$ Canada Trustco, supra note 1 at para. 44. 
and leases. Mission accomplished!? The CCA deductions were allowed by the language of paragraph 20(1)(a) of the Act and related Income Tax Regulations. The Minister challenged the structure under the GAAR, alleging abuse of the "object, spirit and purpose" of these provisions.

The taxpayer prevailed at the Tax Court of Canada and the Federal Court of Appeal. At the Supreme Court, the Chief Justice and Major J. co-wrote the decision for a unanimous court, upholding the lower court decisions.

\section{INTERPRETATION PRINCIPLES}

With respect to statutory interpretation, the Court recognized the modern rule as follows: ${ }^{31}$

It has been long established as a matter of statutory interpretation that "the words of an Act are to be read in their entire context and in their grammatical and ordinary sense harmoniously with the scheme of the Act, the object of the Act, and the intention of Parliament": see 65302 British Columbia Ltd. v. Canada, [1999] 3 S.C.R. 804, at para. 50. The interpretation of a statutory provision must be made according to a textual, contextual and purposive analysis to find a meaning that is harmonious with the Act as a whole.

The relative weight of the textual meaning, contextual meaning and legislative purpose in the interpretive process may vary according to the level of ambiguity of the provision: ${ }^{32}$

When the words of a provision are precise and unequivocal, the ordinary meaning of the words play a dominant role in the interpretive process. On the other hand, where the words can support more than one reasonable meaning, the ordinary meaning of the words plays a lesser role. The relative effects of ordinary meaning, context and purpose on the interpretive process may vary, but in all

\footnotetext{
${ }^{31}$ Canada Trustco, supra note 1 at para. 10.

${ }^{32}$ Ibid.
} 
cases the court must seek to read the provisions of an Act as a harmonious whole.

What separated the new TCP approach from the previous "plain meaning" approach was the Court's emphasis that "in all cases the court must seek to read the provisions of an Act as a harmonious whole”. Under the plain meaning approach, legislative purpose or intent was considered only in cases where the meaning is not clear.

The Court again formally rejected traditional strict interpretation: ${ }^{33}$

As a result of the Duke of Westminster principle (Commissioners of Inland Revenue v. Duke of Westminster, [1936] A.C. 1 (H.L.)) that taxpayers are entitled to arrange their affairs to minimize the amount of tax payable, Canadian tax legislation received a strict interpretation in an era of more literal statutory interpretation than the present. There is no doubt today that all statutes, including the Act, must be interpreted in a textual, contextual and purposive way.

However, the legacy of the Duke of Westminster remains under the TCP approach: the particularity and detail of many tax provisions that often led to an emphasis on textual interpretation; ${ }^{34}$ and the provisions of the Act "must be interpreted in order to achieve consistency, predictability and fairness so that taxpayers may manager their affairs intelligently." 35

Does the TCP apply to the interpretation of all provisions of the Act or only those relevant to the application of the Act? The answer is unclear. The Court seemed to endorse the traditional strict interpretation outside the GAAR: “The Income Tax Act remains an instrument dominated by explicit provisions dictating specific consequences, inviting a largely textual interpretation." 36 To the extent that the GAAR applies, however,

${ }^{33}$ Ibid., at para. 11.

34 Ibid. The Court repeated this in para. 13 that "The Income Tax Act remains an instrument dominated by explicit provisions dictating specific consequences, inviting a largely textual interpretation.”

${ }^{35}$ Ibid., at para. 12.

${ }^{36}$ Ibid., at para. 13. 
"the Duke of Westminster principle and the emphasis on textual interpretation may be attenuated.",37

According to the Court, its role is "to interpret and apply the Act as it was adopted by Parliament". ${ }^{38}$ The Court acknowledged the tension between the GAAR and other provisions of the Act relevant to a particular transaction and appreciated the fact that it must, to the extent possible, contemporaneously give effect to both the GAAR and these other provisions. $^{39}$ Had the Court viewed the TCP as a general interpretation principle, applicable to the interpretation of every provision of the Act, it might not have separated the statutory provisions into the two camps.

\section{INTERPRETATION OF THE GAAR}

Even if it was unclear whether the TCP applies to the Act generally, it clearly applied in the GAAR context. The Court accepted that the purpose of the GAAR is to deny the tax benefits of certain arrangements that comply with a literal interpretation of the provisions of the Act, but amount to an abuse of the provisions of the Act. ${ }^{40}$

As mentioned above, the abuse analysis under subsection 245(4) is a twostep process. The first step is to find the object, spirit and purpose of the specific provision giving rise to the tax benefit; in Canada Trustco, it was paragraph 20(1)(a), which allows a deduction for capital cost allowance. The key term was "cost". The key issue was whether "cost" had a literal or broader meaning to reflect legislative purpose. The taxpayer argued for the ordinary meaning - cost means the price that a taxpayer gave up in order to acquire the asset. ${ }^{41}$ The Minister argued for a broader meaning the economic cost or the amount at risk. The Minister made the following

\footnotetext{
${ }^{37}$ Ibid.

38 Shell Canada v. Canada, [1999] 3 S.C.R. 622 [Shell] at para. 45, cited in Canada Trustco, supra note 1 at para. 13.

${ }^{39}$ Canada Trustco, supra note 1 at para. 13.

${ }^{40}$ Ibid., at para. 16.

${ }^{41}$ Ibid., at para. 71.
} 
submissions. The object and spirit of the CCA provisions are "to provide for the recognition of money spent to acquire qualifying assets to the extent that they are consumed in the income-earning process". 42 Since Canada Trustco's transaction involved no real risk, Canada Trustco did not actually spend $\$ 120$ million to purchase the trailers, and the "cost” of $\$ 120$ million was an illusion. Therefore, the deduction of the illusive cost contravened the object and spirit of the CCA provisions. ${ }^{43}$

The Court was persuaded by the taxpayer's argument. "Textually, the CCA provisions use "cost" in the well-established sense of the amount paid to acquire the assets." 44 This textual meaning was supported by the statutory context (i.e., other provisions of the Act). It was also consistent with the purpose of the CCA provisions, which is "to permit deduction of CCA based on the cost of the assets acquired." 45 How was the court informed of such purpose? "This purpose emerges clearly from the

42 Ibid., at para. 70. The Minister relied on the reasons of Noël J.A. in Water's Edge Village Estates (Phase II) Ltd. v. Canada, [2003] 2 F.C. 25, 2002 FCA 291, at para. 44.

${ }^{43}$ Ibid., at para. 70. The Minister's main submission was summarized as follows:

In this case, the pre-ordained series of transactions misuses and abuses the CCA regime because it manufactures a cost for CCA purposes that does not represent the real economic cost to CTMC of the trailers. CTMC borrowed \$97.4 million from the Royal Bank, but ... the loan was effectively repaid in its entirety on the day it was made. The assignment by CTMC to the Bank of MAIL's rent payments under the lease continued the circular flow of money ... . There was no risk at all that the rent payments would not be made. Even the $\$ 5.9$ million that CTMC apparently paid in fees was fully covered as it, along with the rest of CTMC's contribution of \$24.9 million in funding, will be reimbursed when the \$19 million bond pledged to CTMC matures in December 2005 at \$33.5 million.

CTMC incurred no real economic cost, and thus was not entitled to any "recognition for money spent to acquire qualifying assets"... . [Emphasis added]

${ }^{44}$ Ibid., at para. 74.

45 Ibid. The Court essentially stated that the purpose of the provision is to allow a deduction. However, this does not answer the question as to why the deduction should be allowed in the first place. Also, the Court fails to recognize that the purpose of the CCA provisions in general may be different than the purpose of the CCA provisions related to sale-leaseback transactions. 
scheme of the CCA provisions within the Act as a whole." ${ }^{46}$ Such purpose would be distorted by interpreting "cost" to mean an economic cost or sums of money at economic risk. The Court wrote: ${ }^{47}$

The applicable CCA provisions of the Act do not refer to economic risk. They refer only to "cost". Where Parliament wanted to introduce economic risk into the meaning of cost related to CCA provisions, it did so expressly, as, for instance, in s. 13(7.1) and (7.2) of the Act, which makes adjustments to the cost of depreciable property when a taxpayer receives government assistance. "Cost" in the context of CCA is a well-understood legal concept. It has been carefully defined by the Act and the jurisprudence. Like the Tax Court judge, we see nothing in the GAAR or the object of the CCA provisions that permits us to rewrite them to interpret "cost" to mean "amount economically at risk" in the applicable provisions. To do so would be to invite inconsistent results. The result would vary with the degree of risk in each case. This would offend the goal of the Act to provide sufficient certainty and predictability to permit taxpayers to intelligently order their affairs. For all these reasons, we agree with the Tax Court judge's conclusion that the "cost" was $\$ 120$ million, not zero as argued by the appellant.

In the end, the Supreme Court agreed with the Tax Court that the CCA deduction claimed by Canada Trustco was consistent with the object, spirit and purpose of the CCA provisions and thus not abusive.

\section{MATHEW}

\section{THE CASE}

Standard Trust Company (STC) was a lender of money. In 1991, STC became insolvent with $\$ 52$ million in unrealized losses in a portfolio of mortgages. Because of the insolvency, the losses were "useless" to STC

\footnotetext{
${ }^{46}$ Ibid., at para. 74 .

${ }^{47}$ Ibid., at para. 75 .
} 
as it had no taxable income. In an attempt to maximize the value of those "assets", a series of transactions was undertaken to enable the losses to be deductible by another party. First, STC incorporated a wholly-owned subsidiary and entered into a partnership agreement with it (Partnership A). STC contributed its mortgages to Partnership A and then sold its interest in the partnership to OSFC for \$5 million. STC relied on subsection 18(13) to transfer the portfolio of assets in Partnership A at their historical cost. Partnership B was formed to acquire OSFC's 99 percent interest in Partnership A. The taxpayers in this case became partners of Partnership B. Partnership A liquidated its assets and realized the $\$ 52$ million in losses. Pursuant to subsection 96(1), the losses were allocated to the partners. The taxpayers deducted their share of the losses from their income and reduced their tax liability. The Minister denied the deduction of the losses by relying on the GAAR. The taxpayers argued that the language of subsections 18(13) and 96(1) permitted the deductions.

Unlike Canada Trustco, the taxpayers in this case did not prevail at the Tax Court of Canada or the Federal Court of Appeal. This case became the "poster child" for GAAR-able transactions after the Supreme Court's decision. Like Canada Trustco, McLachlin C.J. and Major J. wrote the decision for a unanimous court.

\section{INTERPRETATION OF SUBSECTIONS 18(13) AND 96(1)}

The issue in this case was whether the transactions, that complied with the textual meaning of subsections 18(13) and 96(1), violated the "object, spirit and purpose” of these provisions.

Subsection 18(13) provides, in essence, that where a taxpayer whose ordinary business includes the lending of money has sustained a loss on a disposition of property used or held in that business, the loss cannot be deducted by the taxpayer if the taxpayer (or a person or partnership that does not deal at arm's length with the taxpayer) owned the same or identical property 30 days before or after the date of the disposition. The amount of loss is added to the cost to the taxpayer of the substituted property. In other words, subsection 18(13) is a "stop-loss" rule. In this case, STC disposed of its portfolio of mortgages to Partnership A in return 
for interest in the partnership. The $\$ 52$ million loss deduction for STC that would normally occur on the disposition was denied, but was added to the cost of the partnership interest.

Subsection 96(1) provides that income or loss of a partner in a partnership is the partner's share of the partnership's income or loss. The taxpayers relied on this provision to receive their share of the losses of Partnership $\mathrm{B}$, which, in turn, received its share of the losses of Partnership A.

The Court applied the textual, contextual and purposive interpretation of these provisions. It noted that "[w]hile it is useful to consider the three elements of statutory interpretation separately to ensure each has received its due, they inevitably intertwine., ${ }^{48}$

In this case, the Court did not provide a clear "textual" interpretation of subsection 18(13) and 96(1). Frankly, the transfer of assets by STC to Partnership A met the technical conditions set forth in subsection 18(13). The allocation of losses to the partners was required by the wording of subsection 96(1). The Court already stated in Canada Trustco: "[w]here Parliament has specified precisely what conditions must be satisfied to achieve a particular result, it is reasonable to assume that Parliament intended that taxpayers would rely on such provisions to achieve the result they prescribe." ${ }^{49}$ Therefore, it appeared that when each provision was interpreted separately, the textual meaning was fairly straightforward. The court recognized this point:

On their face, the partnership provisions found in s. 96 of the Act impose no restrictions on loss sharing between partners, except for foreign partnerships under s. 96(8). Accumulated losses are available to all partners, provided they entered the partnership before the end of the taxation year. It is agreed that the appellants claimed losses in proportion to their interests in Partnership B. Nevertheless, a question arises as to whether these provisions can apply in conjunction with s.

\footnotetext{
${ }^{48}$ Mathew, supra note 2 at para. 43.

${ }^{49}$ Canada Trustco, supra note 1 at para. 11.
} 
18(13) to allow the appellants to claim losses that originated with the original transferor, STC. ${ }^{50}$

The Court moved quickly to the contextual and purposive interpretation. Indeed, there was a great deal of "intertwine" of the three elements. Even under the heading of textual interpretation, the Court "intertwined" it with purposive interpretation: ${ }^{51}$

The requirement that a partnership "not deal at arm's length with the taxpayer" under s. 18(13) and the partnership rules must be purposively construed in relation to each other and in the context of other provisions of the Income Tax Act that address the transfer of losses.

How did the legislative context help clarify the meaning or purpose of subsection 18(13) and 96(1)? The Court first summarized the arguments by the parties, decisions from lower courts, and then concluded that the contextual interpretation was not conclusive ${ }^{52}$ :

The government argues that other provisions of the Act show that the transfer of losses to arm's length parties is generally against the policy of the Act. It is allowed only exceptionally in specific circumstances for specific purposes. The appellants counter that where Parliament wished to prevent the transfer of losses to arm's length parties, it did so explicitly, and that the absence of explicit prohibitions in s. 18(13) and s. 96 permits the inference that Parliament intended to allow such transfers.

The Federal Court of Appeal ... properly concluded that the general policy of the Income Tax Act is to prohibit the transfer of losses between taxpayers, subject to specific exceptions. ... This policy is but one consideration to be taken into account in determining Parliament's intent with respect to s. 18(13) and s. 96.

\footnotetext{
${ }^{50}$ Mathew, supra note 2 at para. 45.

${ }^{51}$ Ibid., at para. 46.

${ }^{52}$ Ibid., at paras. 48-50.
} 
In summary, the legislative context surrounding s. 18(13) and s. 96 of the Income Tax Act, while perhaps not in itself conclusive, suggests that Parliament would not likely have intended arm's length parties to be able to buy losses generated by s. 18(13) transfers.

The most significant aspect of the decision was the Court's approach to finding legislative purpose. First, the purpose was "implicitly" conveyed by the statutory text.

Although, on its face, s. 96(1) imposes no restriction on the flow of losses to its partners, except for the treatment of foreign partnerships under s. 96(8), it is implicit that the rules are applied when partners in a partnership carry on a business in common, in a non-arm's length relationship. ${ }^{53}$

Second, the Court saw a broader purpose from the implicit purpose: ${ }^{54}$

The purpose for the broad treatment of loss sharing between partners is to promote an organizational structure that allows partners to carry on a business in common, in a non-arm's length relationship.

Third, the Court relied on the explicit wording of the provision: ${ }^{55}$

The purpose of s. 18(13) in particular is to prevent a taxpayer who is in the business of lending money from claiming a loss upon the superficial disposition of a mortgage or similar non-capital property. $\cdots$

Under s. 18(13), the loss is generally under the control of the transferor or traceable to the business of the transferor and is preserved because of its special relationship with the transferee partnership. The section in effect denies the loss to the transferor because it originated and remains in the transferor's control before and after the transfer. To allow a new arm's length partner to buy into

\footnotetext{
${ }^{53}$ Ibid., at para. 51.

${ }^{54}$ Ibid., at para. 52.

${ }^{55} \mathrm{Ibid}$., at paras. 53-54.
} 
the transferee partnership and thus to benefit from the loss would violate the fundamental premise underlying s. 18(13) that the loss is preserved because it essentially remains in the transferor's control. It would contradict the main purpose of s. 18(13) and the premise on which it operates. Section 18(13) allows the preservation and transfer of a loss because of the non-arm's length relationship between transferor and transferee. Absent that relationship, there is no reason for the provision to apply. [emphasis added]

The Court concluded that the combined purpose of subsections 18(13) and 96(1) is to disallow taxpayers from transferring losses to arm's length parties. $^{56}$ Since the taxpayers and STC were arm's length parties, the deduction of STC's losses by the taxpayers amounted to abusive tax avoidance. $^{57}$

\section{REVIVING THE MODERN RULE}

In Canada Trustco, the Court restated the modern rule of statutory interpretation as the 'textual, contextual and purposive' approach, but apparently only in the GAAR context. Among the three elements of the interpretation process, textual interpretation remains the most basic. In Canada Trustco, the ordinary meaning of "cost" was held to be consistent with the context and purpose of the CCA provisions. In Mathew, textual interpretation was closely intertwined, and indeed, superseded by contextual and purposive interpretation.

On the basis of these two decisions, legislative context seems to include other provisions of the Act as well as the "policy", although the latter is only one factor. No extrinsic materials were cited by the Court in either case in establishing the legislative purpose of the specific provisions. The Court relied on the text of the provisions, the legislative context (especially the inclusion or absence of certain provisions that may indicate

${ }^{56}$ Ibid., at para. 55. This lends support to Arnold's argument that if the Act was interpreted purposively, there would be no need for the GAAR. See Arnold, "Confusion Worse Confounded", supra note 3 at 181.

${ }^{57}$ Ibid., at para. 58 . 
Parliament's intent), as well as existing case law interpretation of specific provisions. Extrinsic materials were referred to only in Canada Trustco in determining the purpose of the GAAR. ${ }^{58}$

As this was the first time the Court outlined the textual, contextual and purposive analysis, some questions emerge from the judgment. The first question is the relative weight of each element. Although the Court stated that the weight of the three elements will depend on the case, the Court frequently stated that where the text of the provision is clear, the textual interpretation will be emphasized. This raises the question as to what is a clear provision in the Act? Clear to whom - a tax specialist, the average lawyer, a layperson? The Court provided little guidance as to what a clear provision in the Act entails in these two cases. Intuitively, the textual meaning of subsections 18(13) and 96(1) are clear. But, the Court went beyond the textual meaning and looked at the context to determine the purpose of these provisions.

Another question is the extent to which the principle of certainty, predictability and fairness overrides purposive interpretation. ${ }^{59}$ This principle was the main justification for the plain meaning approach. ${ }^{60}$ If the Court is more persuaded by the need for certainty and the taxpayer's right to legitimate tax minimization, the scope of purposive interpretation is inevitably affected. For example, in Canada Trustco, because the term "cost" in the context of CCA "is a well understood legal concept" which "has been carefully defined by the Act and the jurisprudence", replacing it with "amount at economic risk" would invite inconsistencies because of the varying degree at risk in each case. "This would offend the goal of the Act to provide sufficient certainty and predictability to permit taxpayers to intelligently order their affairs." 61

Finally, the most challenging aspect of the revived modern rule is finding the "purpose" of statutory provisions. In Canada Trustco, to the Court, legislative purpose "emerges clearly from the scheme of the CCA

\footnotetext{
${ }^{58}$ Canada Trustco, supra note 1 at para. 15.

${ }^{59}$ Arnold , "Confusion Worse Confounded”, supra note 3 at 178.

${ }^{60}$ Ibid., at 177.

${ }^{61}$ Canada Trustco, supra note 1 at para. 75.
} 
provisions within the Act as a whole." To the government, such purpose was obviously not clear; otherwise they were wasting taxpayer's money litigating the case. In Mathew, the legislative purpose did not "emerge clearly" from the scheme of the Act and the Court relied on implicit text and broader policy to support its finding of the legislative purpose.

\section{Placer Dome - AdVANCing The MOdERN RUle BEYOND GAAR}

\section{A. THE CASE}

Placer Dome is engaged in the international exploration, production and sale of gold. In 1995 and 1996, the taxpayer operated mines in Ontario and was subject to Ontario's Mining Tax Act. ${ }^{62}$ It realized over \$17 million in profits from hedging transactions in those two years. The issue in this case was whether hedging profits were taxable under the Mining Tax Act. While the definition of "hedging" and related provisions remained unchanged, the Minister's administrative policy changed in 1998: until 1998, taxable "hedging" transactions excluded those that did not result in the physical delivery from an Ontario mine; after 1998, the physical delivery of products from an Ontario mine was no longer required. Placer Dome's tax liability in 1995 and 1996 was originally assessed under the earlier administrative practice. The Minister reassessed the taxpayer under the new practice and included the hedging profits in its taxable income. The Minister argued that its new practice correctly interpreted the statue.

Under the Mining Tax Act, mine operators pay tax based on their profit. According to subsection 3(5), profits are calculated by subtracting allowable deductions from "proceeds". Subsection $1(1)^{63}$ contains the following definition "proceeds" and "hedging”:

${ }^{62}$ Mining Tax Act, R.S.O. 1990, c. M.15.

${ }^{63}$ Ibid., s. 1(1). 
"proceeds" means the total consideration that is received or is receivable from another person or persons, in any currency, whether in cash or non-cash form, from the output of the mine, ... and all consideration received or receivable from hedging and future sales or forward sales of the output of the mine, converted at the date of receipt of the consideration to the equivalent in Canadian funds, if receivable in funds of another country.

"hedging" means the fixing of a price for output of a mine before delivery by means of a forward sale or a futures contract on a recognized commodity exchange, or the purchase or sale forward of a foreign currency related directly to the proceeds of the output of a mine, but does not include speculative currency hedging except to the extent that the hedging transaction determines the final price and proceeds for the output.

The taxpayer's appeal was dismissed by the Ontario Superior Court of Justice, but was allowed by the Ontario Court of Appeal. The Minister of Finance appealed to the Supreme Court. LeBel J., writing for a unanimous Supreme Court, allowed the appeal. This elegantly written decision not only clarifies that the modern rule applies generally to the interpretation of tax statutes (including provincial statutes), but also provides further guidance on purposive interpretation.

The Court cited Stubart for the general application of the modern rule to tax statutes. ${ }^{64}$ It then cited Canada Trustco for the emphasis of textual interpretation "because of the degree of precision and detail characteristic of many tax provisions". 65 The Court also recognized that taxpayer's are entitled to rely on the clear meaning of taxation provisions in structuring their affairs. It concluded that:

Where such a provision admits of no ambiguity in its meaning or in its application to the facts, it must simply be applied. ${ }^{66}$

\footnotetext{
${ }^{64}$ Placer Dome, supra note 5 at para. 21.

${ }^{65}$ Ibid., at para. 21.

${ }^{66}$ Ibid., at para. 23.
} 
Was the meaning of the word "hedging" ambiguous in the context of the Mining Tax Act? Apparently - the government argued for a broader meaning to include transactions that do not involve the delivery of Ontario mine products, whereas the taxpayer argued for a narrower meaning, requiring the delivery of Ontario mine products.

Following the three-element TCP approach, the Court started with the textual or ordinary meaning of "hedging" by referring to the Generally Accepted Accounting Principles (GAAP) and Canadian jurisprudence. Under GAAP, a transaction is a "hedge" where a party has assets or liabilities exposed to a particular financial risk and that risk is mitigated by the transaction. For example, to mitigate the risk of fluctuating prices, a party may agree to sell a good in the future at a fixed price (a party looking to buy a good may enter into that transaction for the same reason). The court found that there are two basic categories of transactions forward contracts and options. A forward contract obligates both parties to complete the transaction, whereas an option gives one party the right to complete the transaction. Hedging transactions typically are not settled by the physical delivery of goods. Instead, they are more commonly settled by either cash or an offsetting contract. For GAAP purposes, the method of settlement is irrelevant to the characterization of a transaction as a "hedge”. Furthermore, as illustrated by Echo Bay Mines Ltd. v. Canada 67 , financial transactions not settled by physical delivery of the output of an Ontario mine may "fix the price" for that output and act as a hedge.

The meaning of "hedging" in the statutory context was established by the Court by examining the statutory definition of the term, its relationship with the definition of "proceeds", and the legislative history of the statutory definition of "hedging”. The Court stated:

It follows that "the fixing of a price for output of a mine" cannot be restricted to transactions that are settled by delivery of output. This is, in my opinion, consistent with the context of the statutory definition. In addition to "the fixing of a price ... by means of a forward sale", the definition of "hedging" refers to "the fixing of a price ... by means

${ }^{67}$ [1992] 3 F.C. 707. 
of ... a futures contract on a recognized commodity exchange", "the purchase or sale forward of a foreign currency related directly to the proceeds of the output of a mine", and "does not include speculative currency hedging". It is significant that futures contracts are seldom settled by physical delivery. Similarly, a sale or purchase forward of foreign currency is a separate transaction from the sale of an underlying commodity and would not itself be settled by physical delivery of the commodity. In short, the other elements in the statutory definition of "hedging" are consistent with the broader interpretation. ${ }^{68}$

Therefore, the Court rejected the taxpayer's narrow interpretation - the price for the output of an Ontario mine could only be "fixed" by a transaction that was settled physically. ${ }^{69}$ If this interpretation was accepted, the Court reasoned, all consideration from hedging would fall into the first or third component of the term "proceeds", leaving the second component (all consideration from hedging) unnecessary. ${ }^{70}$ According to the presumption against tautology, "every word in a statute is presumed to make sense and to have a specific role to play in advancing the legislative purpose."71 Since the definition of hedging was introduced in the Mining Tax Act for a term that only appears once, the presumption against tautology carried considerable weight. ${ }^{72}$

\footnotetext{
${ }^{68}$ Ibid., at para. 47.

${ }^{69}$ Ibid., at para. 36.

${ }^{70}$ Ibid., at para. 44.

71 Ruth Sullivan, ed., Driedger on the Construction of Statutes, $3^{\text {rd }}$ ed. (Toronto: Butterworths, 1994) cited in Placer Dome, supra note 5 at para. 45.

72 Placer Dome, supra note 5 at para. 46. The Court decided that the term "hedging" cannot be interpreted narrowly. However, the broad interpretation does create some problems. Consideration in the "proceeds" context is generally a gross amount, but consideration from "hedging" is a net amount. However, this consequence, in the Court's opinion, doesn't outweigh the absurdity that would occur if "hedging” were interpreted narrowly: Ibid., at para. 51.
} 


\section{B. Advancing the Modern Rule}

The Placer Dome decision advanced the application of the modern rule in several respects. First, it confirmed that TCP applies to tax statutes in general.

Second, it provided an example of establishing a purposive meaning by relying on the integrity of the legislative scheme. It gave effect to the interpretive presumption that "[e]very word in a statute is presumed to make sense and to have a specific role to play in advancing the legislative purpose."73 The Court stated:

To the extent that it is possible to do so, courts should avoid adopting interpretations that render any portion of a statute meaningless or redundant: Hill v. William Hill (Park Lane) Ld., [1949] A.C. 530 (H.L.), at p. 546, per Viscount Simon. ${ }^{74}$

Third, the Court adopted another important presumption in finding legislative intent - the presumption against absurdity. It stated:

The Mining Tax Act defines "hedging" as the fixing of a price for the output of a mine before delivery by means of, inter alia, a forward sale. Options, as Cullity J. noted, are simply contingent forward sales, and they fix the price for output in much the same way that forward contracts do. To attach substantially different tax consequences, within the context of a provision that taxes "proceeds from hedging" to two forms of transactions that serve the same function as hedging tools would be an absurd result that the legislature could not have intended. $^{75}$

Finally, the Court relied on evidence in rejecting the taxpayer's argument for certainty and predictability, as opposed to simply "imagining" or "predicting” uncertainty. The Court stated: ${ }^{76}$

\footnotetext{
${ }^{73}$ Ibid., at para. 45.

${ }^{74}$ Ibid.

${ }^{75}$ Ibid., at para. 52.

${ }^{76}$ Ibid., at para. 50.
} 
The fact that the taxpayer can and does, presumably on a principled basis, determine whether hedging profits relate directly to the output of a mine, for the purpose of claiming the resource allowance under the Income Tax Act and the Ontario Corporations Tax Act belies PDC's predictability argument. I note, in this vein, that PDC used the same financial information that it submitted with its tax return under the Mining Tax Act to claim that its hedging gains qualified as "resource profits" so as to entitle it to the resource allowance under the Corporations Tax Act.

\section{IMPERIAL OIL - THE MODERN RULE SPLITS THE COURT}

\section{A. THE DECISION}

This case involved two corporate taxpayers - Imperial Oil and Inco. The issue was whether paragraph 20(1)(f) of the Act permitted the deduction of foreign exchange losses incurred in the redemption of debt obligations or whether it is limited to the deduction of original issue discounts.

Imperial Oil had issued debentures denominated in U.S. dollars. Between the date of issue and the date of redemption of the debentures, the U.S. dollar had appreciated against the Canadian dollar. The taxpayer suffered a loss on redemption of C $\$ 27.8$ million representing the original discount and the foreign exchange loss. Imperial Oil took the position that it was entitled to deduct the entire loss under subparagraph 20(1)(f)(i) of the Act. In the alternative, it took the position that it was entitled to a deduction under subparagraph 20(1)(f)(ii) and that the non-deductible 25 percent under that formula was by default a capital loss under subsection 39(2). The Minister took the position that the entire loss of C\$27.8 million was predominantly a capital loss deductible under subsection 39(2).

In 1989, Inco issued sinking fund debentures of US\$150 million at a discount of 2.6 percent (US\$ 3.9 million). When Inco retired the debentures with American currency already on hand, it suffered a loss and 
deducted it under paragraph 20(1)(f). The Minister disallowed the deduction.

Paragraph 20(1)(f) permits the taxpayer to deduct the amount by which the original issue proceeds of the debt are exceeded by the amount paid in satisfaction of the principal amount of the debt. It provides that when computing income from business, a deduction is allowed where:

(f) an amount paid in the year in satisfaction of the principal amount of any bond, debenture, ... issued by the taxpayer ... on which interest was stipulated to be payable, to the extent that the amount so paid does not exceed,

(i) in any case where the obligation was issued for an amount not less than $97 \%$ of its principal amount, and the yield from the obligation ... does not exceed $4 / 3$ of the interest stipulated to be payable on the obligation, ... the amount by which the lesser of the principal amount of the obligation and all amounts paid in the year or in any preceding year in satisfaction of its principal amount exceeds the amount for which the obligation was issued,

and

(ii) in any other case, $3 / 4$ of the lesser of the amount so paid and the amount by which the lesser of the principal amount of the obligation and all amounts paid in the year or in any proceeding taxation year in satisfaction of its principal amount exceeds the amount for which the obligation was issued.

The issue in this case was whether the deduction under paragraph 20(1)(f) is limited to a "discount" arising from the original issuance of the debt, or is it broad enough to include costs related to borrowing in a foreign currency (such as foreign exchange losses)?

The Minister argued for a narrow interpretation. According to the Minister, foreign exchange losses are not addressed by paragraph 20(1)(f). 
The exchange rate applicable to the calculation of the principal amount is an amount in Canadian dollars, fixed on the date of issue. If the exchange rate is fixed on the issue date, then no discount due to foreign exchange losses can exist. Since no other specific provision would apply, subsection 39(2) - a residual provision - would apply, treating the foreign exchange losses as capital losses. The Minister's position relied on determining Parliament's intent, by examining intrinsic and extrinsic evidence.

The taxpayers argued that paragraph 20(1)(f) allows for the deduction of foreign exchange losses. They argued that when an obligation is issued in foreign currency, the principal amount is fixed on the date of disposition. This would allow the fluctuation of the currency to create foreign exchange gains or losses to expand or reduce the discount deductible under the paragraph. The taxpayers relied on determining the purpose of paragraph 20(1)(f) by examining the definition of "principal amount" in subsection 248(1) and how that expression is used in other provisions of the Act.

The Supreme Court was split four to three. ${ }^{77}$ LeBel J. wrote the majority decision and Binnie J. authored the dissenting judgment.

In the GAAR cases, the goal of the interpretive exercise is to establish the "object, spirit and purpose" of a statutory provision in order to determine if that object, spirit and purpose is abused. In non-GAAR cases, such as this case, the statutory text, context and scheme are used as evidence of finding legislative intent or purpose. The legislative intent or purpose is then used to illuminate which textual interpretation is more compatible with such intent or purpose.

\footnotetext{
${ }^{77}$ The Tax Court of Canada allowed Imperial Oil's appeal in part - allowing a partial deduction. The Federal Court of Appeal also allowed Imperial Oil's appeal in part, allowing a greater deduction than the Tax Court. The Tax Court of Canada dismissed Inco's appeal. The Federal Court of Appeal allowed Inco's appeal based on its decision in Imperial Oil.
} 


\section{B. THE MAJORITY}

LeBel J. reiterated the general principles governing the interpretation of the Act. $^{78}$ He emphasized that "[w]hether foreign exchange losses are covered by s. 20(1)(f) must be ascertained with respect to the text, scheme and context of that provision., ${ }^{, 79}$

Looking at the text of paragraph 20(1)(f), LeBel J. noted that the word "discount" was absent and there was no express mention of foreign currency exchanges. However, the opening words of subparagraph 20(1)(f)(i) set out what is commonly accepted as the definition of a discount. The text of this provision thus suggested that the "primary referent of s. 20(1)(f) is something other than foreign exchange losses, namely, payments in the nature of discounts." ${ }^{80}$ When the provision was applied to Canadian dollar obligations, paragraph 20(1)(f) isolated the difference between the principal amount of the obligation and the amount for which it was issued - the discount. When the difference is three percent or less, the discount is fully deductible under subparagraph 20(1)(f)(i) and when it is greater than three percent, it is deductible at the capital rate under subparagraph 20(1)(f)(ii). ${ }^{81}$ Therefore, when applied to Canadian dollar obligations, each branch has a clear application and applies to all original issue discounts. LeBel J. concluded that the deduction in paragraph 20(1)(f) "does not encompass the appreciation or depreciation of the principal amount over time."

LeBel J. examined whether in the context of debts issued in foreign currency, does the wording in paragraph 20(1)(f) permit the deduction of foreign exchange losses? Subparagraph 20(1)(f)(i) applied "in any case where the obligation was issued for an amount not less than 97 percent of its principal amount", while subparagraph 20(1)(f)(ii) applied "in any

\footnotetext{
${ }^{78}$ Imperial Oil, supra note 6 at para. 27.

${ }^{79}$ Ibid., at para. 61.

${ }^{80}$ Ibid., at para. 62.

${ }^{81}$ Ibid.

${ }^{82}$ Ibid. He agreed with Miller J. in Imperial Oil Limited v. Canada, [2004] 2 C.T.C. 3030, 2004 TCC 207 at para. 44.
} 
other case". This led to the question does the phrase "in any other case" in subparagraph 20(1)(f)(ii) refer to "any case in which the obligation was issued for an amount less than 97 percent" or to "any case in which the cost of repaying the principal amount exceeds the amount for which the debt was issued"? The taxpayers argued the latter. LeBel J. opined that the "better reading of the opening words of s. 20(1)(f)(ii) is the one that preserves a higher degree of parallelism of expression (i.e., 'any case in which the obligation was issued for an amount less than 97\%')." ${ }^{83}$ In other words, paragraph 20(1)(f) addressed the deductibility of original issue discounts.

LeBel J. recognized that the calculation of a "discount" is based on the "principal amount". If the principal amount of debt is issued in a foreign currency that can fluctuate, with the cost of repayment in Canadian dollars, then the discount amount may encompass discounts arising out of fluctuations of the currency over time. ${ }^{84}$ This led to another question: does the statutory definition of "principal amount" in subsection 248(1) contemplate the possibility that the principal amount can be the amount payable in Canadian currency at the time of issue or the time of redemption. If it is the latter, foreign exchange losses would be included. To resolve this ambiguity, LeBel $\mathrm{J}$. found it necessary to determine whether Parliament intended foreign exchange losses to be covered by paragraph 20(1)(f) in the same way as discounts. ${ }^{85}$

${ }^{83}$ Ibid., at para. 64 . This statement reflects a presumption against internal inconsistency or self-defeating. The Presumption states that courts should not presume that Parliament intended to allow taxpayers to defeat its intention through contrived, artificial transactions. See Jinyan Li, ““Economic Substance”: Legitimate Tax Minimization vs. Abusive Tax Avoidance" (2006) 54 Can. Tax. J. 23 at 39. In this case, this reading of paragraph 20(1)(f) would not defeat Parliament intention of having foreign exchange losses as part of the capital regime, instead of the income regime.

${ }^{84}$ Ibid., at para. 64. LeBel J. states "the 'discount amount' can be ascertained in relation to the value of the principal in Canadian dollars at the time of repayment, rather than in relation to the face value of the obligation (i.e., the term 'discount' may not be limited to 'original issue discounts' but may encompass discounts that arise out of fluctuations of commodity or currency prices over time)."

${ }^{85}$ Ibid., at para. 64. 
In LeBel's view, “s. 20(1)(f) was never intended to apply to foreign exchange losses." ${ }^{66}$ He gave the following reasons for his conclusion:

First, the scheme of subsection 20(1) indicates that only expenses arising directly out of the borrower-lender relationship are deductible because other costs enumerated in s. 20 are intrinsic costs of borrowing, such as interest payments and premiums. Since a foreign exchange loss "is a cost of borrowing only where the thing borrowed is foreign currency", it is not an intrinsic cost of borrowing, and thus not deductible.

Second, an interpretation of paragraph 20(1)(f) that allows the deduction of foreign exchange losses means that this section "would operate quite differently in relation to obligations denominated in foreign currency than it does in relation to obligations denominated in Canadian dollars. ${ }^{87}$

In the context of foreign currency obligations, the deduction would reflect the appreciation or depreciation of the principal amount over time, whereas in the context of Canadian dollar obligations, the deduction would reflect a point-in-time expense. In the context of foreign currency obligations, the s. 20(1)(f) deduction would accordingly be available even where, as in Inco, there was no original issue discount. [This] approach also has the effect of altering the distinction between the two branches of s. $20(1)(f) .{ }^{88}$

Therefore, Parliament could not have intended such a differential tax treatment as it would create incentives to structure obligations in a particular way.

Third, the broader context of the Act, such as subsection 39(2), sheds light on legislative intent. If paragraph 20(1)(f) is interpreted to allow a deduction of foreign exchange losses, which have been traditionally characterized as on account of capital, ${ }^{89}$ it would create conflicts with the

\footnotetext{
${ }^{86}$ Ibid., at para. 67.

${ }^{87}$ Ibid., at para. 66.

${ }^{88}$ Ibid.

${ }^{89}$ Ibid., at para. 32. The majority identified that borrowing is characterized as a payment on account of capital because the characterization of a foreign exchange gain or loss
} 
general scheme of the Act treating capital gains and losses separately. More specifically, it would fail to "properly appreciate the role of s. 39", which was a "statement of Parliament's intent to treat foreign exchange losses as capital losses." 90

Fourth, the broad statement that "Parliament encourages companies to raise capital by allowing them to deduct virtually all costs of borrowing under the provisions of s. 20(1)" "91 was not persuasive. Paragraph 18(1)(b), for example, provides that payments on account of capital may not be deducted from business income unless the deduction thereof is expressly permitted. Therefore, not all costs of borrowing are deductible under paragraph 20(1)(f).

Ultimately, LeBel rejected the taxpayer's argument. He stated: ${ }^{92}$

[It] turns s. 20(1)(f) into a broad provision allowing for the deductibility of a wide range of costs attendant upon financing in foreign currency, in the absence of any mention of such costs in the text of the ITA, and despite the fact that such costs are usually regarded as being on capital account.

\section{THE DISSENT}

Binnie J. agreed with LeBel J. that paragraph 20(1)(f) should be interpreted textually, contextually and purposively. ${ }^{93}$ However, he emphasized more of a textual interpretation by vividly describing the provisions of the Act as the "rules of engagement" for the "battlefield on which over 21 million Canadian taxpayers engage with the Minister of

generally follows the characterization of the underlying transaction. This is important because paragraph 18(1)(b) prohibits the deduction of amounts paid on account of capital unless it is specifically allowed by another section.

${ }^{90}$ Ibid., at para. 68.

${ }^{91}$ Ibid., at para. 65.

${ }^{92}$ Ibid., at para. 67.

${ }^{93}$ Ibid., at para. 75. 
National Revenue."94 He also indicated his discomfort with relying on legislative intent and his preference for legislative purpose. In the end, he agreed with the taxpayers and held that foreign exchange losses are deductible.

Binnie J.'s textual interpretation began with the recognition of the role of section 20 being a specific provision to allow the deduction of "various capital amounts" to override paragraph 18(1)(b). As such, he recognized that the foreign exchange losses were on account of capital and could only be deductible against income by virtue of section 20. He found that this provision "permits a deduction of the amount by which the original issue proceeds of the debt are exceeded by the amount paid in satisfaction of the principal amount of the debt."95

He then noted that the expression "principal amount" was used nine times in the course of paragraph 20(1)(f), signalling its importance. "Principal amount" is defined in subsection 248(1) to mean the amount that "is the maximum amount or maximum total amount, as the case may be, payable on account of the obligation by the issuer". In the context of debt issued in a foreign currency, since Canadian dollars must be used for the purposes of the Act, the maximum amount payable can only be determined on the date of redemption, not the date of the issuance of the debt. ${ }^{96}$ Thus, the relevant exchange rate is the rate prevailing at the date of redemption. "It is not until that date that it is possible to determine the "maximum amount ... payable on account of the obligation" as required by the statutory definition of "principal amount". ${ }^{97}$

Binnie J. cited a number of instances where the Minister has allowed deductions under paragraph 20(1)(f) for obligations other than those with original issue discounts. ${ }^{98}$ He stated that in those cases, the "principal amount" could not be calculated until the date of repayment that the actual

\footnotetext{
${ }^{94}$ Ibid., at para. 73.

${ }^{95}$ Ibid., at para. 83.

${ }^{96}$ Ibid., at para. 85.

${ }^{97}$ Ibid., at para. 83.

${ }^{98}$ Ibid., at paras. 88-92.
} 
cost of satisfying the obligation could be ascertained in Canadian dollars. ${ }^{99}$ Binnie J. also considered foreign exchange losses as a cost that arises directly out of the debtor-creditor relationship. ${ }^{100}$

Textually interpreted, Binnie J. concluded that paragraph 20(1)(f) allows the deduction of the discounts computed by comparing the total principal amount fixed on the date of redemption and the original proceeds of issuance.

The broader statutory context, including subsection 39(2), section 79 and section 80, was not considered helpful. Subsection 39(2) is a residual provision and applies only to the extent that a foreign currency loss is not otherwise deductible in computing income. ${ }^{101}$ He also noted that sections 79 and 80 specifically state that the calculation is to be based on the value of the foreign debt in Canadian currency on the issuance date. There is no such specification in paragraph 20(1)(f). Therefore, "there is little help to be had from other sections of the Act." ${ }^{\text {102 }}$

On the last part of the interpretative process, Binnie J. disagreed with LeBel J.'s conclusion that paragraph 20(1)(f) is designed to address a specific class of financing costs arising out of the issuance of debt instruments at a discount.

\section{BASIS FOR THE SPLIT}

The majority and the dissent followed the same principle of statutory interpretation and the same process of textual, contextual and purposive interpretation, but reached different interpretations of paragraph 20(1)(f). They seem to differ on several issues discussed below.

\footnotetext{
${ }^{99}$ Ibid., at para. 92.

${ }^{100}$ Ibid., at para. 79.

${ }^{101}$ Ibid., at para. 99.

${ }^{102}$ Ibid., at para 101.
} 


\section{NOT ALL WORDS ARE EQUAL IN THE TEXTUAL INTERPRETATION}

The Court put a different emphasis on different elements of the statutory text. According to LeBel J., the opening words of subparagraph 20(1)(f)(i) set out what is commonly accepted as the definition of a discount. $^{103}$ Also, there is no express mention of a foreign currency exchange. In interpreting the term "principal amount", LeBel J. referred to the statutory definition in subsection 248(1), but found it inconclusive as it "does not expressly address whether or how foreign currency fluctuations are to be taken into account in determining the "principal amount" of an obligation denominated in foreign currency" and there was no indication that "foreign currency conversions were in Parliament's contemplation when that section was drafted." 104

On the other hand, Binnie J. emphasized the term "principal amount", apparently because it is used nine times in paragraph 20(1)(f). He noted that the definition of "principal amount" is the maximum amount or maximum total amount payable on account of the obligation by the issuer. In the case of a foreign issue obligation that contracts the issuer to pay foreign currency at a future date, the maximum amount actually payable on account of the obligation is unknown and unknowable at the time of issuance and can only be ascertained at the date fixed for redemption. ${ }^{105}$ Binnie J. did not examine the meaning of other words used in paragraph 20(1)(f).

\section{LEGISLATIVE SCHEME}

The scheme of the Act is important under the modern rule, which specifically requires that the meaning of the statutory words be "in their grammatical and ordinary sense harmoniously with the scheme of the Act, the object of the Act, and the intention of Parliament". In Canada Trustco, the Court seemed to have collapsed the "scheme" element into either

\footnotetext{
103 Ibid., at para. 62.

${ }^{104}$ Ibid., at para. 61.

105 Ibid., at para. 86.
} 
“context” or "purposive” element of the rephrased "textual, contextual and purposive" approach. The Court emphasized in Canada Trustco that:

The relative effects of ordinary meaning, context and purpose on the interpretive process may vary, but in all cases the court must seek to read the provisions of an Act as a harmonious whole. ${ }^{106}$

The phrase "the provisions of an Act as a harmonious whole" expresses the idea of "legislative scheme". Therefore, legislative scheme is an important element of statutory interpretation.

LeBel J. specifically referred to the "scheme" of subsection 20(1) as one factor in rejecting the taxpayers' argument. The scheme allows a deduction for intrinsic cost of borrowing and foreign exchange loss is not such a cost. In his opinion, "the scheme of s. 20, although not dispositive, does not assist the respondent.”

LeBel J. also appreciated the fact that the Act has separate schemes for capital gains and losses and income gains and losses:

Despite its undeniable - and growing - complexity, the current federal ITA displays some fundamental structural characteristics. One of these characteristics, which is provided for in s. 3, is the distinction between income and capital. Capital gains are only partially brought into income for taxation purposes. ${ }^{107}$

Because subsection 20(1) is part of the income regime, allowing deductions against income, only capital amounts that are specified under subsection 20(1) (such as interest and capital cost allowance) are deductible. Permitting a deduction for foreign exchange losses, which are on capital account, in the absence of expressed authorization under subsection 20(1), lead to "conflicts with the general treatment of capital gains and losses in the ITA.” LeBel J. correctly stated that the taxpayer's argument (which was accepted by Binnie J.) "indicates a failure to

\footnotetext{
106 Canada Trustco, supra note 1 at para. 10.

${ }^{107}$ Imperial Oil, supra note 6 at para. 17.
} 
properly appreciate the role of s. 39", which is a statement of Parliament's intent to treat foreign exchange losses as capital losses." ${ }^{108}$

Binnie J. did not mention the legislative scheme at all. To him, section 39 was of little relevance. ${ }^{109}$ His failure to properly appreciate the separate regime for income and capital is clearly demonstrated by his following remarks: ${ }^{110}$

It all comes back to the simple proposition that in Canadian tax terms foreign currency is a commodity, and its fluctuations will inevitably carry costs (or benefits). Had the Canadian dollar appreciated against the U.S. dollar in the relevant period of time, for instance, the taxpayers would have lost the original issue discount to which they might otherwise have been entitled. What the taxing authority loses on the swings it will make up on the roundabouts. At the end of the day it will have its just desserts.

Binnie J.'s statement is incorrect. Foreign exchange gains and losses are generally on capital account to Imperial Oil, Inco, and other taxpayers who are not currency traders. As such, capital expenditures are not deductible in the absence of a specific provision under section 20. Even if paragraph 20(1)(f) was interpreted to allow a deduction for foreign exchange losses, there is no equivalent provision to tax foreign exchange gains as income. Therefore, foreign exchange gains are not the "just desserts" to offset the deduction for foreign exchange losses. While taxpayers will argue for a full deduction for the loss under paragraph 20(1)(f), they will surely not argue for full inclusion of the gain. Instead, foreign exchange gains will be treated on capital account, partially taxable. ${ }^{111}$ The differential treatment of full deduction for the loss and partial inclusion for the gain can be appreciated only when one appreciates the scheme of the Act.

\footnotetext{
${ }^{108}$ Ibid., at para. 68 .

${ }^{109}$ Ibid., at para. 99.

${ }^{110}$ Ibid., at para. 104.

${ }^{111}$ This is what happened in Shell Canada where the taxpayer deducted the interest at full nominal rate for a weak-currency loan and included the foreign exchange gains from a related forward contract as capital gains.
} 


\section{LEGISLATIVE INTENT OR PURPOSE}

In previous cases, the Court was not clear in referring to "purpose" or "intent" and tended to use them interchangeably. In Imperial Oil, LeBel J. seemed to emphasize legislative intent, whereas Binnie J. favored legislative purpose.

LeBel J. concluded that the text, context and scheme of the Act indicate that Parliament did not intend to allow a deduction for foreign exchange losses when enacting s.20(1)(f). ${ }^{112}$ He noted that the taxpayers argued that the purpose of paragraph 20(1)(f) was to encourage Canadian companies to raise capital on the global market, but did not rely on it to displace the legislative intent. In Binnie J.'s view, such legislative intent was unexpressed in specific words of the Act and should not be used to override clear textual meaning. Moreover, Binnie J. found that LeBel J.'s interpretation of paragraph 20(1)(f) would defeat the legislative purpose. Only a broader interpretation of paragraph 20(1)(f) would be consistent with such purpose.

While LeBel J. found legislative intent on the basis of the text and scheme of the Act, it is unclear as to the basis used by Binnie J. in establishing the legislative purpose. He referred to the legislative history of some of the deductions $^{113}$ under subsection 20(1), but not paragraph 20(1)(f) per se. ${ }^{114}$ The path for finding legislative purpose is not clear.

The overall logic for Binnie J.’s reliance on “legislative purpose” as opposed to legislative intent is problematic. Binnie J. offered two reasons for rejecting legislative intent. First, Parliament's intent “is nowhere

${ }^{112}$ Ibid., at para. 67.

${ }^{113}$ In Montreal Coke and Manufacturing v. Minister of National Revenue, [1944] A.C. 126 (P.C.). 1942, the Supreme Court held that the costs incurred in refinancing a company's debt are not deductible against revenue for the purpose of calculating income tax. In response to this, Parliament enacted a series of provisions to deem various costs of capital borrowings to be deductible because they recognized that capital borrowings are used to productively generate income.

${ }^{114}$ Imperial Oil, supra note 6 at para. 104. 
expressed in the Act, although it would have been a simple thing to say so if that was Parliament's intent." He provided no examples where Parliament's intent is expressed in the Act. Second, "finding unexpressed legislative intentions under the guise of purposive interpretation runs the risk of upsetting the balance Parliament has attempted to strike in the Act."115

While troubled by relying on unexpressed legislative intent, Binnie J. was not worried at all about the unexpressed legislative purpose. Instead, he agreed with LeBel J.'s observation that "Parliament encourages companies to raise capital by allowing them to deduct virtually all costs of borrowing under the provisions of s. 20(1)". Naturally, allowing the deduction of foreign exchange losses advance such purpose. Denying the deduction would act as a deterrent. Furthermore, given the modest size of the Canadian capital market, ${ }^{116}$ "it would be counterproductive in a global economy to discourage foreign borrowings." ${ }^{\text {"117 }}$ Binnie J. did not apply his criticism of legislative intent to his own approach: how would such purposive interpretation of paragraph 20(1)(f) preserve "the balance Parliament has attempted to strike in the Act"? What is the "balance" in the first place?

The way that Binnie J. pit "legislative intent" against "legislative purpose" is unfortunate. Many provisions in the Act originate from the 1917 Act or subsequent amendments. Given the change in the complexity of business today and the sophistication of tax advisors, it is likely that these provisions are used in ways that Parliament never intended. ${ }^{118}$ Perhaps out of this concern, LeBel J. did not see legislative intent and purpose to be mutually exclusive. In the same paragraph of his decision, he used both terms:

\footnotetext{
${ }^{115}$ Shell, supra note 38 at para. 43, cited Imperial Oil, supra note 6 at para. 102.

${ }^{116}$ Imperial Oil, supra note 6, para.70.

${ }^{117}$ Ibid., at para. 103.

${ }^{118}$ The fact that these provisions haven't been modified is not conclusive either since either Parliament sees no need to amend the provision or that they didn't foresee that the provision could be used in that manner.
} 
This interpretation best reflects the structure of the ITA and the intent of Parliament. The purpose of the provision is to address a specific class of financing costs arising out of the issuance of debt instruments at a discount. ${ }^{119}$

\section{THE BABY STEPS}

The four decisions reviewed in this article indicate that the Court is prepared to slowly move away from the plain meaning approach towards a "textual, contextual and purposive" approach or the modern rule. In our view, the move is in the right direction, but the steps taken are merely "baby steps". The Court has yet to provide adequate details on the implementation of the new approach.

On the general principle of statutory interpretation, the Court has revived the modern rule on a timid, hesitant and unsteady footing. In each of the four cases, the Court emphasized the importance of textual interpretation following the citation of the modern rule. It could be viewed as continuing the plain meaning approach. ${ }^{120}$ The Court also qualified the modern rule with the principle of certainty, predictability and fairness and the respect for the right of taxpayers' to legitimate tax minimization. Nonetheless, the Court has taken the first step in moving beyond pure textual interpretation. In none of the four cases did the Court refuse to examine the context and purpose of the statutory provisions. In Placer Dome and Imperial Oil, LeBel J. did not accept the argument that the long-standing administrative position be adopted, even if such position was used and relied upon by taxpayers. Even Binnie J. did not reject an examination of legislative purpose in Imperial Oil, even though he limited the utility of such examination to reveal latent ambiguity in the statutory text. ${ }^{121}$

\footnotetext{
${ }^{119}$ Imperial Oil, supra note 6 at para. 67.

120 See Arnold, “Confusion Worse Confounded”, supra note 14 at 683. Arnold argues that the TCP approach in Canada Trustco and Placer Dome is nothing more than the plain meaning approach.

${ }^{121}$ Imperial Oil, supra note 6 at para. 97.
} 
The relative weight of text, context, and purpose in the interpretation analysis depends on the case. Generally speaking, however, as mentioned above, more weight is given to the text when the provision is written specifically. This provides little guidance because determining when a provision in a taxing statute is written specifically is a subjective assessment. Moreover, as illustrated in the Imperial Oil case, different judges may emphasize different elements of the text.

The most under-developed element of the TCP approach is legislative purpose. The dominant view seems to be that legislative purpose and intent can be referred to interchangeably. However, in Imperial Oil, a strong dissent pit "purpose" against "intent" and rejected the latter for very persuasive reasons. The basis and process for establishing legislative intent or purpose have yet to be coherently and comprehensively articulated. Clearly, little guidance can be found in the following statements:

The purpose of CCA provisions emerges clearly. ${ }^{122}$

The purpose for the broad treatment of loss sharing between partners is to promote an organizational structure that allows partners to carry on a business in common, in a non-arm's length relationship"

Parliament encourages companies to raise capital by allowing them to deduct virtually all costs of borrowing under the provisions of $\mathrm{s}$. $20(1) .^{124}$

It is difficult to imagine that a litigant in a tax case can argue the purpose or intent of a statutory provision without referring to any extrinsic materials or scheme of the Act. LeBel J.'s approach to purposive analysis in Placer Dome and Imperial Oil is thus far the most sophisticated. He referred to the text, legislative scheme and structure, interpretive presumptions, and some extrinsic materials.

${ }^{122}$ Canada Trustco, supra note 1 at para. 74. The Tax Court did a better job in purposive analysis. See 2003 TCC 215 at paras. 59-68.

${ }^{123}$ Mathew, supra note 2 at para. 52.

${ }^{124}$ Imperial Oil, supra note 6 at paras 67 and 103. 


\section{MOVING FORWARD}

\section{A. GREEN-LIGHT ON}

Applying the modern rule to the interpretation of a complex statute such as the Act is inherently difficult. ${ }^{125}$ The provisions of taxing statutes are difficult to interpret because of they are technical, detailed and drafted in a specific manner. The meaning and purpose of a specific provision may be well-hidden in the quagmire of rules. The Court has traditionally wanted as little a role as possible in the making of tax law. ${ }^{126}$ They may not want to stray into what appears to be creation of new rules that Parliament might have introduced had it thought about it but which, in fact, it did not. ${ }^{127}$ This conservative attitude has kept the courts from becoming a cooperative law-making partner of Parliament in the tax law sphere. ${ }^{128}$

There are reasons to be optimistic about the Court's moving forward with applying the modern rule in the interpretation of the Act. First, within a two-year time period, the Court first adopted the modern rule in Canada Trustco and Mathew in the GAAR context, then expanded it in Placer Dome and Imperial Oil to tax statutes in general. The momentum has been extremely impressive. The level of sophistication in applying the modern rule, although far from satisfactory, has improved greatly from Canada Trustco to Imperial

Oil.

Second, it would be difficult to revert back to plain meaning approach because of the GAAR. As the Court correctly recognized, the GAAR

${ }^{125}$ For further discussion, see Hogg, Magee and Li, Principles of Canadian Income Tax Law (6th edition) (2007), ch.19.

${ }^{126}$ See e.g. Shell, supra note 38.

127 Judith Freedman, "Converging Tracks? Recent Developments in Canadian and UK Approaches to Tax Avoidance” (2005) 53 Can. Tax. J. 1038.

${ }^{128}$ See Neil Brooks, “The Responsibility of Judges in Interpreting Tax Legislation” in Graeme S. Cooper, ed., Tax Avoidance and the Rule of Law (Amsterdam: IBFD Publications in association with the Australian Tax Research Foundation, 1997). 
demands a purposive interpretation. Since the GAAR is potentially applicable to many provisions of the Act, it would be very odd to switch the interpretative approach depending on whether GAAR is invoked. It is time that the Court treats tax statutes like other statutes and apply the modern rule. In a sense, the GAAR has the effect of being a general rule of statutory interpretation. ${ }^{129}$ It would be difficult for judges to fall back on the strict interpretation or plain meaning with GAAR in the Act. With the departure of Iaccobucci J., the main author of the decisions advocating the plain meaning approach, ${ }^{130}$ Binnie J. may champion the more textual interpretive approach, but he is surely mindful of the need to look at the legislative purpose. Also, it will be interesting to see which approach Rothstein J., who authored some important tax decisions while on the Federal Court of Appeal ${ }^{131}$, will support.

Third, the Court sent a strong signal about the revival of the modern rule. The decisions in Canada Trustco, Mathew and Placer Dome are unanimous, and the Chief Justice co-authored the first two decisions, and concurred with LeBel J. in Placer Dome and Imperial Oil. However, the four to three split in Imperial Oil is worrisome because the rationale used by Binnie J. would represent a step back from purposive interpretation. ${ }^{132}$

Finally, LeBel J.’s decisions in Placer Dome and Imperial Oil serve as good precedents. His reference to the statutory text, scheme and structure, as well as interpretative aids in interpretation is refreshing and illuminating.

\footnotetext{
129 This then calls into question the continuing need for the GAAR. See supra note 56.

${ }^{130}$ See Duff (2007), supra note 14.

${ }^{131}$ See e.g. OSFC Holdings Ltd. v. R, [2001] 4 C.T.C. 82, 2001 D.T.C. 5471 (F.C.A.); 722540 Ontario Inc. [Novopharm Limited] v. R, [2003] 3 C.T.C. 1, 2003 D.T.C. 5195 (F.C.A.); Canadian Pacific Limited v. R, [2002] 2 C.T.C. 197, 2002 D.T.C. 6742 (F.C.A.).

132 The fact that Binnie J. was supported by two members of the Court would suggest that a return to the plain meaning approach, or some other label to a strict approach, is possible. However, Binnie J's position may be affected by the particular facts of the case, including the fact that the Minister's administrative practice seemed to support the taxpayer's argument.
} 


\section{B. SUGGESTED MOVES}

In order to move beyond baby steps in interpreting the Act according to the modern rule, the courts should assume that the meaning of the statutory words is ambiguous and engage in contextual and purposive analysis. It would be unfortunate if the courts continue to find "clear and plain" meaning when equally talented and devoted lawyers representing the taxpayer and the government disagree on the meaning of the same words.

Moreover, the courts should not view the Act just as the rules of engagement for the "battlefield" between taxpayers and the government. The Act is a huge government spending statute and a tool of redistribution and social justice. As early as 1984, Estey J. recognized the changing role of the Act and used it as an impetus for the initial adoption of the modern rule. Surely, today's Court can see the multiple roles of the Act more clearly and further implement the modern rule.

The Court should assume a more active role in tax law-making through interpretation. It should seriously consider the presumptions, including presumption against tautology, presumption against absurd results, and against self-defeating or internal inconsistency, as important canons of statutory interpretation. Of course, lawyers need to help the court with evidence of statutory scheme and extrinsic materials. 